UTILITY: Jurnal Ilmiah Pendidikan dan Ekonomi

Volume 3, No. 1, Februari 2019: Page 45-54

ISSN 2549-1377 (Print) || ISSN 2549-1385 (Online)

Available online at http://journal.stkipnurulhuda.ac.id/index.php/utility

\title{
PENGARUH SIKAP BELAJAR PESERTA DIDIK DAN MINAT BELAJAR PESERTA DIDIK TERHADAP PRESTASI BELAJAR EKONOMI KELAS XI DI MA NURUL HUDA SUKARAJA
}

\author{
Wiwit Puji Lestari ${ }^{1}$, Dwi Susanti ${ }^{2}$, Miftahur Rohmah ${ }^{3}$ \\ 1,2,3 Program Studi Pendidikan Ekonomi,STKIP Nurul Huda Sukaraja Oku Timur \\ *E-mail: hajjahmiftahu15@gmail.com
}

\begin{abstract}
Abstrak:Penelitian ini dilatar belakangi konsep bahwa keberhasilan belajar dipengaruhi oleh faktor internal seperti sikap dan minat sehingga hal tersebut menarik untuk dilakukan penelitian lebih lanjut. Tujuan penelitian ini adalah untuk mengetahui pengaruh sikap belajar peserta didik dan minat belajar vpeserta didik terhadap prestasi belajar ekonomi kelas xi di ma nurul huda sukaraja.Penelitian dilaksanakan menggunakan jenis kuantitatif. Variabel bebas pada penelitian ini adalah sikap (X1) dan minat (X1), sedangkan variabel terikat penelitian ini adalah prestasi belajar ekonomi. Teknik pengumpulan data yang digunkan adalah angket dan dokumentasi. Analisis data dilakukan menggunakan rumus product moment korelasi dan regresi ganda.Hasil penelitian: Pertama: Sikap belajar peserta didik kelas XI MA Nurul Huda Sukaraja adalah sedang yaitu dari 26 peserta didik terdapat 15 peserta didik atau 57,69\% menjawab sikap belajar masuk kategori sedang dengan nilai rata-rata hasil angket 65,8077 dan standar deviasi 10. Kedua: Minat belajar peserta didik kelas XI MA Nurul Huda Sukaraja adalah sedang yaitu dari 26 peserta didik terdapat 17 peserta didik atau $65,38 \%$ menjawab minat belajar masuk kategori sedang dengan nilai rata-rata hasil angket 66,2692 dan standar deviasi 11. Ketiga: Prestasi belajar peserta didik kelas XI MA Nurul Huda Sukaraja adalah sedang yaitu dari 26 peserta didik terdapat 18 peserta didik atau 69,23\% menjawab prestasi belajar masuk kategori sedang dengan nilai rata-rata hasil angket 79,9615 dan standar deviasi 11. Keempat: terdapat pengaruh yang kuat atau tinggi antara sikap belajar peserta dan minat belajar peserta didik terhadap prestasi belajar ekonomi kelas XI dengan indeks korelasi sebesar 0,96 yang berada diantara 0,81 - 1,00. Hasil uji hipotesis menunjukkan bahwa nilai Fo $=540,73$, Fo $<\operatorname{Fo}(26)(26)$ yaitu 540,73 > 1,99 sehingga hipotesis nihil H0 ditolak sedangkan Ha diterima.
\end{abstract}

Kata Kunci: Pemanfaatan Buku-buku Perpustakaan, Lingkungan Keluarga, Prestasi Belajar.

\section{PENDAHULUAN}

Pendidikan merupakan salah satu tempat untuk meningkatkan kualitas sumber daya manusia. Hal tersebut sebagaimana tertuang dalam Undangundang Repuplik Indonesia Nomer 20 Tahun 2003 tentang sistem pendidikan Nasional Bab II pasal 3 bahwa:

Pendidikan Nasional berfungsi mengembangkan kemampuan dalam membentuk watak serta beradaban bangsa yang bermartabat dalam rangka mencerdaskan kehidupan bangsa, 
bertujuan untuk berkembangnya potensi peserta didik agar menjadi manusia yang beriman dan bertaqwa kepada tuhan yang maha Esa, berakhlak mulia, sehat, berilmu, cakap, kreatif, mandiri dan menjadi warga negara yang demokratis serta bertanggung jawab.

Berkaitan dengan belajar, Menurut Slameto (2010:2), Belajar ialah suatu proses usaha yang di lakuakan seseorang untuk memperoleh suatu perubahan tingkah laku yang baru secara keseluruhan, sebagai hasil pengalamannya sendiri dalam interaksi dengan lingkungannya. Berdasarkan pengertian tersebut, belajar dikatakan berhasil jika seseorang mampu mengulangi kembali materi yang telah di pelajarinya. Ketercapaian proses belajar sebagaimana tersebut dapat di istilahkan dengan prestasi belajar.

Prestasi belajar merupakan hasil belajar yang dicapai setelah melalui proses kegiatan belajar mengajar. Prestasi belajar dipengaruhi oleh beberapa faktor, Menurut Syah (2013:145), mengemukakan berbagai faktor yang mempengaruhi belajar siswa yaitu faktor yang berasal dari dalam diri siswa, dari luar siswa. Faktor yang berasal dari dalam diri siswa yaitu meliputi seluruh kondisi baik fisiologis maupun psikologis individu peserta didik yang sedang belajar seperti intelegensi, sikap, bakat, minat, dan motivasi. Salah satu bentuk prestasi belajar yang diupayakan diraih melalui bidang pendidikan adalah prestasi belajar pelajaran ekonomi.

Penjelasan sebagaiana tersebut menunjukkan bahwa diantara faktor intern yang mempengaruhi ketercapaian prestasi belajar peserta didik adalah faktor sikap dan minat. Berkaitan faktor sikap, Dimyati (2013:239) menjelaskan, sikap adalah kemampuan memberikan penilaian tentang sesuatu, yang membawa diri sesuai dengan penilaian. Sikap peserta didik terhadap mata pelajaran Ekonomi yang positif merupakan pertanda awal yang baik bagi proses belajar siswa itu sendiri, jika sikap peserta didik terhadap mata pelajaran ekonomi positif maka akan merespon pelajaran dengan baik dan prestasi yang dicapai akan baik pula dan sebaliknya jika sikap siswa terhadap mata pelajaran Ekonomi negatif maka akan menimbulkan respon yang kurang baik dan menyebabkan prestasi belajarnya pun tidak optimal. Oleh karena itu, untuk mengoptimalkan prestasi belajar peserta didik yaitu peserta didik harus mempunyai minat.

Belajar dapat dilakukan dengan semangat apabila siswa memiliki minat belajar. Menurut Slameto (2010:57) Minat adalah kecenderungan yang tetap 
untuk memperhatikan dan mengenang beberapa kegiatan. Peserta didik yang menaruh minat besar terhadap pelajaran akan memusatkan perhatian lebih banyak, seperti halnya mau mendengarkan, berkonsentrasi dan mau menanggapi materi yang disampaikan oleh guru sebaliknya peserta didik yang tidak mempunyai minat dalam proses belajar tidak akan menerima materi yang disampaikan guru. Dari uaraian tersebut dapat disimpulkan bahwa sikap dan minat belajar peserta didik yang positif dapat mempengaruhi prestasi belajar yang tinggi.

Berdasarkan hasil pengamatan pada saat melaksanakan Program Pengalaman Lapangan II di MA Nurul Huda Sukaraja yang dilaksanakan pada Tagal 23 September s.d 23 November 2017. Peneliti tertarik untuk menganalisis sikap dan minat belajar peserta didik terhadap prestasi belajar peserta didik. Penelitian ini dilaksanakan di MA Nurul Huda Sukaraja. Pemilihan lokasi penelitian ini dikarenakan dekat dengan tempat penelitian yang berkaitan dengan sikap belajar dan minat belajar peserta didik. Pengamatan yang dilakukan peneliti bahwa prestasi belajar peserta didik kelas XI MA Nurul Huda Sukaraja pada mata pelajaran ekonomi sangat beragam. Hal ini dapat terbukti dari Ujian Tengah Semester Ganjil yang belum merata. Dari kelas XI IPS MA Nurul Huda Sukaraja yang berjumlah 26 peserta didik terdapat peserta didik yang memperoleh nilai ulangan harian 75 yang berarti sudah diatas standar yang di tetapkan yaitu 72 Kriteria Ketuntasan Minimum (KKM) tetapi ada juga peserta didik yang memperoleh nilai 50 yang berarti belum mencapai Kriteria Ketuntasan Minimum (KKM) dalam belajar. Hasil pengamatan sikap belajar peserta didik di MA Nurul Huda Sukaraja terdapat 6 peserta didik yang belum optimal dalam proses belajar mengajar di kelas pada mata pelajaran Ekonomi, terbukti dari peserta didik yang tidak merespon guru pada saat memberikan materi di dalam kelas, sering keluar masuk kelas saat proses belajar mengajar berlangsung, dan ada peserta didik yang tidur di kelas. Dan hasil pengamamatan minat belajar pada mata pelajaran Ekonomi terdapat 8 peserta didik yang masih kurang, ditunjukkan dari peserta didik yang kurang berkonsentrasi dalam belajar, tidak sepenuhnya mendengarkan pelajaran yang disampaikan guru, dan tidak menanggapi pertanyaan yang diberikan guru.

\section{METODE}


Dalam penelitian ini jenis penelitiannya adalah penelitian kuantitatif. Sudjana (2010:18) mengemukakan, "penelitian kuantitatif adalah penelitian menggunakan data kuantitatif atau data berbentuk angka". Desain penelitian ini adalah desain penelitian korelasional. Sukardi (2011:166) menyatakan "penelitian korelasional merupakan bagian penelitian ex-postfacto karena tidak memanipulasi keadaan variabel dan langsung mencari tingkat hubungan variabel yang direfleksikan pada koefesien korelasi”. Variabel penelitian di dalam penelitian ini ada dua, yang pertama yaitu variabel bebasnya atau yang mempengaruhi adalah sikpa belajar peserta didik dan minat belajar peserta didik $(\mathrm{X})$, sedangkan variabel terikatnya yaitu prestasi belajar $(\mathrm{Y})$.

Penelitian ini dilakukan di MA Nurul Huda Sukaraja dengan populasi 75 peserta didik. Sampel penelitian ini adalah peserta didik kelas XI MA Nurul Huda Sukaraja dengan jumlah 26 peserta didik dengan pengambilan sampel menggunakan teknik cluster random sampling. Sugiyono (2010:121) mengatakan teknik cluster sampling adalah teknik pengambilan sampel dengan cara menentukan daerah atau bagian. Teknik ini dilaksanakan dengan menggunakan stratified random sampling.

Pengumpulan data menggunakan angket dan dokumentasi (nilai raport). Dalam penelitian ini uji instrumen menggunakan uji validitas dan reliabilitas. Data yang diperoleh dari sampel penelitian kemudian dianalisis sesuai dengan metode statistik yang digunakan lalu dipresentasikan. Uji analisis data menggunakan korelasi dan regresi berganda, uji hipotesis menggunakan uji F.

\section{HASIL DAN PEMBAHASAN}

Hasil dari penelitian pengaruh sikap belajar peserta didik dan minat belajar peserta didik terhadap prestasi belajar ekonomi kelas XI di MA Nurul Huda Sukaraja dapat diuraikan berikut:

\section{Sikap Belajar}

Data sikap belajar pada penelitian ini diketahui dengan menggunakan instrumen angket. Berdasarkan analisis data hasil anget sikap belajar diketahui bahwa sikap belajar peserta didik kelas XI MA Nurul huda Sukaraja adalah sedang. Hal tersebut dibuktikan dengan perolehan skor hasil angket yang menunjukkan bahwa dari 26 peserta didik terdapat 6 peserta didik atau 23,08\% menjawab sikap belajar dalam kategori tinggi, sedangkan 15 peserta didik atau 
57,69\% menjawab sikap belajar dalam kategori sedang, sedangkan 5 peserta didik atau 19,23\% menjawab sikap belajar dalam kategori rendah dengan nilai rata-rata hasil angket 65,8077 dan standar deviasi 10.

Jadi hasil penelitian menunjukkan bahwa mayoritas sikap belajar peserta didik kelas XI MA Nurul Huda Sukaraja adalah sedang. Peserta didik yang memiliki sikap belajar sedang, akan lebih mudah menerima informasi yang diberikan oleh guru. Hal ini dikaitkan dengan pendapat ahli Winkel (2009:117) Orang yang bersikap tertentu, cenderung menerima suatu objek berdasarkan penilaian terhadap objek itu. Apabila sikapnya sedang maka untuk menyimpan informasi dari guru juga bisa maksimal. Perlunya guru yang kreatif dalam mengajar, agar dapat memberikan respon positif dalam belajar. Menurut Allport dalam Djaali (2009:115) bahwa sikap itu tidak muncul seketika atau dibawa lahir, tetapi disusun dan dibentuk melalui pengalaman serta memberikan pengaruh langsung kepada respon orang.

\section{Minat Belajar}

Data minat belajar pada penelitian ini diketahui dengan menggunakan instrumen angket. Berdasarkan analisis data hasil angket minat belajar diketahui bahwa minat belajar peserta didik kelas XI MA Nurul Huda Sukaraja adalah sedang. Hal tersebut dibuktikan dari perolehan skor hasil angket yang menunjukkan bahwa dari 26 peserta didik terdapat 4 peserta didik atau $15,38 \%$ menjawab minat belajar dalam kategori tinggi, sedangkan 17 peserta didik atau 65,38\% menjawab minat belajar dalam kategori sedang, sedangkan 5 peserta didik atau 19,23\% menjawab minat belajar dalam kategori rendah dengan nilai rata-rata hasil angket 66,2692 dan standar deviasi 11.

Jadi hasil penelitian menunjukkan bahwa mayoritas minat belajar peserta didik kelas XI MA Nurul Huda Sukaraja adalah sedang. Minat besar pengaruhnya terhadap belajar, karena bila minat belajarnya sedang peserta didik akan belajar dengan sebaik-baiknya. Hal ini serupa dengan pendapat Purwanto (2010:66) mengatakan bahwa minat merupakan landasan penting bagi seseorang untuk melakukan kegiatan dengan baik. Kegiatan yang di minati peserta didik, akan di perhatikan terus-menerus yang disertai dengan rasa senang. Sama halnya dengan pendapat Djamarah (2008:191) minat adalah suatu rasa lebih suka dan rasa ketertarikan pada suatu hal atau aktifitas tanpa ada yang menyuruh. 


\section{Prestasi Belajar Peserta didik}

Prestasi merupakan hasil dari suatu kegiatan telah dikerjakan, diciptakan baik secara individual maupun kelompok. Jadi prestasi belajar merupakan perolehan yang telah dicapai oleh seseorang ketika mengerjakan tugas atau kegiatan tugas atau kegiatan tertentu. Prestasi belajar dalam kegiatan akademik bersifat kognitif yang diketahui melalui penilaian pada akhir pembelajaran.

Data presttasi belajar peserta didik pada penelitian ini diketahui dengan menggunakan teknik dokumentasi nilai rapor semester genap. Hasil analisis data nilai peserta didik menunjukkan bahwa prestasi belajar peserta didik kelas XI MA Nurul Huda Sukaraja adalah sedang. Hal tersebut dibuktikan dari perolehan dari nilai dokumentasi yang menunjukkan bahwa dari 26 peserta didik terdapat 4 peserta didik atau 15,38 \% mendapat nilai dalam kategori tinggi, sedangkan 18 peserta didik atau 69,23\% mendapat nilai dalam kategori sedang, sedangkan 4 peserta didik atau 15,38 \% mendapat nilai dalam kategori rendah dengan nilai rata-rata hasil angket 79,9615 dan setandar deviasi 11.

Jadi hasil penelitian menunjukkan bahwa mayoritas prestasi belajar peserta didik kelas XI MA Nurul Huda Sukaraja adalah sedang. Peserta didik yang mempunyai prestasi belajar yang sedang kemungkinan dikarenakan beberapa faktor, seperti sikap dan minatnya dalam belajar juga sedang. peserta didik akan mencapai prestasi yang sesuai dengan perencanaan apabila melakuakan dengan sungguh-sungguh. Menurut pendapat ahli Syah (2012:141) mengatakan bahwa prestasi adalah tingkat keberhasilan siswa mencapai tujuan yang telah ditetapkan dalam sebuah program.

\section{Pengaruh Sikap Belajar dan Minat Belajar terhadap Prestasi Belajar Peserta Didik}

Setelah masing-masing data dari tiap variabel independent dianalis, langkah selanjutnya adalah melakukan analis data variabel independent tersebut terhadap variabel dependent. Proses analis data variabel independent terhadap variabel dependent penelitian dilakukan dengan menggunakan teknik korelasi product moment. Berdasarkan analisis data diperoleh nilai $\mathbf{r}_{1.2} 0,96$ yang kemudian nilai tersebut diinterpretasikan dengan tabel interpretasi korelasi product moment diketahui bahwa sikap belajar dan minat belajar peserta didik mempunya korelasi tinggi atau sangat kuat terhadap prestasi 
belajar peserta didik kelas XI di MA Nurul Huda Sukaraja. Oleh karena itu dapat disimpulkan bahwa sikap belajar dan minat belajar memiliki pengaruh tinggi atau sangat kuat terhadap prestasi belajar peserta didik kelas XI di MA Nurul Huda Sukaraja karena harga $r_{1.2}$ berada diantara 0,800 - 0,100.

Setelah diketahui analisis nilai variabel $\mathrm{X}_{1}, \mathrm{X}_{2}$ dan $\mathrm{Y}$, langkah selanjutnya adalah melakukan uji persamaan uji regresi berganda variabel X1 dengan hasil $-0,104$ berarti terdapat pengaruh negatif antara sikap belajar terhadap prestasi belajar peserta didik. Artinya setiap ada penurunan sikap belajar, maka akan diikuti dengan penurunan prestasi belajar peserta didik. Dan Variabel $\mathrm{X}_{2}$ sebesar 0,349 berarti terdapat pengaruh positif antara minat belajar dengan prestasi belajar peserta didik. Artinya setiap ada kenaikan minat belajar, maka akan diikuti dengan kenaikan prestasi belajar peserta didik.

Langkah selanjutnya yaitu menguji hipotesis. Uji hipotesis digunakan uji statistik koefesien korelasi berganda. Uji statistik koefisien korelasi berganda digunakan untuk menguji signifikan atau tidaknya hubungan lebih dari dua variabel. Untuk koefesien korelasi berganda, uji statistiknya menggunakan $\mathrm{F}_{\mathrm{o}}$. Berdasarkan perhitungan diperoleh nilai $F_{o}$ 540,73. Angka tersebut kemudian dibandingkan dengan harga $\mathrm{F}$ tabel untuk taraf signifikasi 5\% dengan ketentuan $\mathrm{v}_{1}=26$ dan $\mathrm{v}_{2}=26$. Pada tabel $\mathrm{v}_{1}=26$ dan $\mathrm{v}_{2}=26$ diperoleh harga $\mathrm{F}=1$,99. Berdasarkan ketentuan tersebut maka diketahui bahwa $\mathrm{F}_{\mathrm{o}}<\mathrm{F}_{(26)(26)}$ yaitu 540,73>1,99 oleh karena itu hipotesis $\mathrm{H}_{0}$ ditolak dan $\mathrm{H}_{\mathrm{a}}$ diterima.

Bukti penelitian ini juga didukung oleh pernyataan Slameto (2010:54) prestasi belajar dapat dipengaruhi oleh sikap dan miat. Hasil penelitian ini membuktikan bahwa sikap belajar dan minat belajar merupakan faktor yang mempengaruhi dan memiliki pengaruh secara bersama atau secara simultan terhadap prestasi belajar peserta didik kelas XI di MA Nurul Huda Sukaraja.

\section{SIMPULAN}

Sikap belajar peserta didik kelas XI di MA Nurul Huda Sukaraja adalah sedang. Hal tersebut dibuktikan dengan perolehan skor hasil angket yang menunjukkan bahwa dari 26 peserta didik terdapat 6 peserta didik atau 23,08\% menjawab sikap belajar dalam kategori tinggi, sedangkan15 peserta didik atau $57,69 \%$ menjawab sikap belajar dalam kategori sedang, sedangkan 5 peserta 
didik atau 19,23\% menjawab disiplin belajar dalam kategori rendah dengan nilai rata-rata hasil angket 65,8077 dan standar deviasi 10. Minat belajar peserta didik kelas XI di MA Nurul Huda Sukaraja adalah sedang. Hal tersebut dibuktikan dari perolehan skor hasil angket yang menunjukkan bahwa dari 26 peserta didik terdapat 4 peserta didik atau $15,38 \%$ menjawab minat belajar dalam kategori tinggi, sedangkan 17 peserta didik atau 65,38\% menjawab minat belajar dalam kategori sedang, sedangkan 5 peserta didik atau 19,23\% menjawab minat belajar dalam kategori rendah dengan nilai ratarata hasil angket 66,2692 dan standar deviasi 11. Prestasi belajar belajar peserta didik peserta didik kelas XI di MA Nurul Huda Sukaraja adalah sedang. Hal tersebut dibuktikan dari perolehan dari nilai dokumentasi yang menunjukkan bahwa dari 26 peserta didik terdapat 4 peserta didik atau 15,38 $\%$ mendapat nilai dalam kategori tinggi, sedangkan 18 peserta didik atau 69,23 $\%$ mendapat nilai dalam kategori sedang, sedangkan 4 peserta didik atau 15,38 $\%$ mendapat nilai dalam kategori rendah dengan nilai rata-rata hasil angket 79,9615 dan setandar deviasi 11. Terdapat pengaruh yang kuat atau tinggi antara sikap belajar dan minat belajar peserta didik dengan indeks korelasi sebesar 0,96 yang berada diantara 0,81-0,100. Hasil uji hipotesis menunjukkan bahwa nilai $\mathrm{F} 0=540,73<1,99$. Oleh karena itu hipotesis $(\mathrm{Ho})$ ditolak sedangkan $(\mathrm{Ha})$ diterima.

\section{UCAPAN TERIMAKASIH}

Ucapan terimakasih ditujukan kepada STKIP Nurul Huda Sukaraja yang menjadi bagian perjalanan menempuh pendidikan Sarjana Pendidikan Ekonomi dan juga kepada seluruh pihak yang telah ikut serta dalam pembuatan skripsi penulis. Kepada kedua orang tua dan kedua pembimbing penulis, serta teman-teman seperjuangan yang telah menorehkan banyak cerita dan juga pengalaman. Nomor : 070/71/Ban. KBPM/2018.

\section{SARAN}

Berdasarkan hasil penelitian yang menunjukkan adanya pengaruh sikap belajar peserta didik dan minat belajar peserta didik yang signifikan terhadap prestasi belajar ekonomi kelas XI di MA Nurul Huda Sukaraja maka dapat disarankan sebagai berikut: Bagi peserta didik di MA Nurul Huda Sukaraja supaya senantiasa meningkatkan sikap belajar dan minat belajar agar dapat 
mencapai prestasi belajar yang maksimal demi tercapainya masa depan peserta didik yang cerah. Bagi MA Nurul Huda Sukaraja hasil penelitian ini diharapkan dapat dijadikan acuan pihak sekolah dalam menumbuhkan sikap belajar peserta didik sehingga dapat menunjang prestasi belajar peserta didik yang lebih optimal. Bagi peneliti selanjutnya agar dapat melakukan penelitian lebih lanjut tentang sikap belajar dan minat belajar terhadap prestasi belajar peserta didik sehinga akan mempermudah proses pembelajaran bagi peserta didik dan hasil penelitian ini dapat dijadikan sebagai kajian pustaka sebagai dasar untuk melaksanakan penelitian-penelitian serupa dengan berpedoman dengan kode etik penelitian.

\section{REFERENSI}

Depdiknas. 2003. Undang-undang RI No. 20 tahun 2003 Tentang sistem Pendidikan Nasional. Jakarta : Depdiknas.

Slameto. 2010. Belajar dan Faktor-faktor Yang Mempengaruhinya. Jakarta: Rineka Cipta.

Syah, Muhibin. 2013. Psikologi Belajar. Jakarta : Rineka Cipta.

Dimyati. 2013. Belajar dan Pembelajaran. Jakarta : PT. Rineka Cipta.

Nana Sudjana. 2010. Penilaian Hasil Proses Belajar Mengajar. Bandung: Remaja Rosdakarya.

Sukardi. 2011. Metodologi Penelitian Pendidikan. Jakarta: Bumi Aksara.

Sugiyono. (2010). Statistika untuk penelitian. Bandung: Alfabeta.

Winkel. 2009. Psikologi Pengajaran. Yogyakarta : Media Abadi.

Djaali. 2009. Psikologi Pendidikan. Jakarta : Bumi Aksara.

Purwanto. 2010. Evaluasi Hasil belajar. Yogyakarta: Pustaka Pelajar.

Djamarah, Syiful. 2010. Psikologi Belajar. Jakarta : PT. Rineka Cipta. 